\title{
TECCIENCLA
}

\section{Determination of the probability and rate of corrosion on reinforced concrete specimens through a remote corrosion monitoring system}

\section{Determinación de la probabilidad y tasa de corrosión sobre probetas de concreto reforzado mediante un sistema de monitoreo remoto de corrosión}

\author{
Fredy Bernal Castillo ${ }^{1 *}$, Guillermo Roa-Rodríguez ${ }^{2}$, Carlos Cabrera Cabrera ${ }^{3}$, \\ Nicolás Sierra-Melo ${ }^{4}$, William Aperador ${ }^{5}$ \\ I*Universidad Militar Nueva Granada, Bogotá, Colombia, fdbernalc@gmail.com \\ ${ }^{2}$ Universidad Militar Nueva Granada, Bogotá, Colombia, Guillermo.rrg@gmail.com \\ ${ }^{3}$ Universidad Militar Nueva Granada, Bogotá, Colombia, U1801998@unimilitar.edu.co \\ ${ }^{4}$ Universidad Militar Nueva Granada, Bogotá, Colombia, U1802367@ unimilitar.edu.co \\ ${ }^{5}$ Universidad Militar Nueva Granada, Bogotá, Colombia, g.ing.materiales@gmail.com
}

\begin{abstract}
In this paper, we present the design and construction of a remote monitoring system for determining the probability and rate of corrosion of rebar embedded in concrete. We use the ASTM standard C876 technique for the probability of corrosion and the Linear Polarization Resistance method to indirectly obtain the rate of corrosion. The system consists of a communication module using GSM and GPRS cellular networks which provide remote measurements. The device was used to evaluate corrosion with reference electrodes of copper/copper sulfate and graphite on Type I Portland cement specimens of $15 \mathrm{~cm}$ in diameter and $30 \mathrm{~cm}$ in length. The results of the measurements were compared to a commercial system, revealing similar values to the data obtained in the field and the laboratory.
\end{abstract}

Keywords: Corrosion Monitoring, Half Cell Potential, Linear Polarization Resistance, Reinforced Concrete, rebar corrosion.

\section{Resumen}

Este trabajo presenta el diseño y construcción de un sistema de monitoreo remoto de corrosión con el cual es posible determinar la probabilidad y velocidad de corrosión de un segmento de acero estructural embebido en concreto. De acuerdo a la norma ASTM C876 el sistema permite determinar las probabilidades de corrosión, así mismo la medición de la velocidad de corrosión fue desarrollada a partir de la técnica de la resistencia a la polarización lineal, consignada en el estándar ASTM G59. El equipo fue implementado a partir de un módulo de adquisición y almacenamiento de datos en memoria física, el cual fue complementado con un sistema de comunicación inalámbrica celular que permite hacer uso de las redes GSM y GPRS proporcionando las características de medición remota del sistema. El equipo se utilizó para evaluar el estado corrosivo en probetas de concreto fabricadas con cemento portland Tipo I de 15 centímetros de diámetro y 30 centímetros de longitud usando electrodos de referencia de cobre/sulfato de cobre y grafito. Los resultados de las mediciones fueron contrastadas con un equipo comercial encontrando un error promedio de medición del $0.20 \%$ para las probabilidades de corrosión y un error promedio del $1.17 \%$ para los valores de resistencia a la polarización lineal lo cual permitió determinar la precisión de las mediciones remotas realizadas mediante el equipo desarrollado.

Palabras Clave: Monitoreo de corrosión, Potencial de media celda, Resistencia de Polarización Lineal, Concreto reforzado, corrosión de armaduras.

*Corresponding Author.

E-mail: fdbernalc@gmail.com,

Address: , carrera 11 \# 101-80

Phone: (+57) 15600000 ext. 1273
How to cite: * Bernal Castillo, F.; Roa-Rodríguez, G.; Cabrera Cabrera, C.; Sierra Melo, N.; Aperador, W.; Determination of the probability and rate of corrosion on reinforced concrete specimens through a remote corrosion monitoring system, TECCIENCIA, Vol. 10 No. 19., 2731, 2015, DOI: http:/dx.doi.org/10.18180/tecciencia.2015.19.5 


\section{Introduction}

Reinforced concrete structures exhibit excellent mechanical behavior under specific environmental conditions in civil infrastructure, depending largely on manufacturing processes and the quality of the cement [1] [2]. One of the greatest risks for such structures is the corrosion of the reinforcing steel bars - or rebar - inside of the concrete coating, which causes deterioration and cracking in different types of constructions. The increase in the corrosion of the cross section due to the constant deposition of elements generates stress over the cement paste, consequently producing cracks that can cause general defects with the passage of time [3].

Embedded rebar is insulated from the oxidation processes in large part due to a thin layer of oxide generated by the high level of alkalinity, a result of the concrete manufacturing process, with $\mathrm{pH}$ values above 12.5 . The interaction of the structure with aggressive materials decreases the alkaline reserve present in the concrete and removes the protective layer of oxide present in the steel [1] [4]. Some of these aggressive materials could be carbon dioxide in polluted cities or chloride ions in marine and saline environments. The chloride ions migrate to the rebar through a process of diffusion. The phenomenon can be divided into two stages propagation and initiation. The propagation stage begins at the moment in which the ions penetrate the concrete without directly affecting the steel reinforcement. The initiation phase is generated when the concentration of chlorides reaches a critical level. The aforementioned aggressive ions enter through the exposed sides via microcracks and pores found in the concrete. The speed with which the chloride ions enter varies according to the properties of the mix, especially the proportion of water to cement [4].

Carbonation is one of the leading causes of the deterioration of reinforced concrete structures in places with high levels of $\mathrm{CO} 2$, such as urban centers and parking lot structures. Given the degree of air pollution and $\mathrm{CO} 2$ in the main cities, one can expect concrete structures to show advanced states of carbonation. According to pathology studies on buildings and bridges in big cities, some structures were shown deterioration from rebar corrosion attributable to carbonation [5] [6]. Due to the greater porosity of cement pastes with a high water-to-cement ratio, the impact of carbonation on the structure increases. Moreover, carbonation has been shown to amplify when the quantity of cement is decreased [7] [8] due to the consequent reduction in alkaline reserve. Likewise, the rate of carbonation has been shown to depend on the type of cement. Cement with pozzolanic materials added, which is the majority of cement in the world, produce pastes with a lower quantity of calcium hydroxide and thus a lower alkaline reserve. They are less resistant to deterioration from carbonation [9].
As a result, maintenance and reconstruction costs for these affected structures currently represent a hefty portion of the costs of civil infrastructure. It thus becomes necessary to monitor building quality, as well as carry out adequate maintenance and planning for the restoration of at-risk structures. Various electrochemical techniques have been employed with the aim of pinpointing areas with deterioration from corrosion. These have made it possible to predict the lifespan of the structure and likewise make decisions regarding required refurbishments or protections according to the level of damage. Among these electrochemical measures, the ASTM standard C876-91 has proved both versatile and efficient in determining the probability of corrosion in reinforced concrete structures.

With that in mind, in this paper we present a device that allows for the remote monitoring of steel reinforcement corrosion in reinforced concrete structures. To do so, we determine the probability of corrosion by applying ASTM standard C879-91 and the velocity of corrosion using the technique of linear polarization resistance (LPR). With these, it is possible to establish the probability of a corrosive state and the rate of the deterioration of the embedded rebar without needing to send technical personnel to the field.

\section{Materials and methods}

We designed and constructed a system for remotely monitoring the open circuit potential and determining the velocity of corrosion by performing an LPR electrochemical trial. The aim was to evaluate the behavior of reinforced concrete structure in the face of corrosion, without the need to dispatch personnel and equipment to the field every time a measurement is required.

The ASTM standard C879-09 was used as a starting point to obtain the half-cell potential. The technique allows one to obtain, through the utilization of a voltage gauge, the difference in potential between a reference electrode and the rebar. The probability of structural corrosion is thus indicated based on the voltage obtained from the measurements, as seen in Table 1

Table 1 Probability of corrosion vs Potential of corrosion

\begin{tabular}{|c|c|}
\hline Probability of corrosion & $\begin{array}{c}\text { Potential of corrosion vs } \\
\text { electrode } \mathbf{C u} / \mathrm{CuSO}_{4} / \mathbf{V}\end{array}$ \\
\hline $10 \%$ & $>0.2$ \\
\hline Uncertainty & $-0.2>$ to $>-0.35$ \\
\hline Greater than $90 \%$ & $<-0.35$ \\
\hline
\end{tabular}

Likewise, the embeddable adaptation of the standard and the measuring process was performed with the aim of indefinitely and permanently obtaining the value of the potential in the rebar. This was done by inserting a probe, based on reference electrodes, into the paste. The adaptation of the system was made using an embeddable copper/copper 
sulfate $(\mathrm{Cu} / \mathrm{CuSO} 4)$ electrode as the reference electrode and the rebar as the working electrode. We used a 3-pin XLR connector for the connection of the electrodes to the equipment, as it offers robustness and isolation of the external noise signal. Prior to the installation of the electrode, the probe had been soaked for 30 seconds in potable water. It was then inserted into a hole, 3 inches in diameter and 10 inches in depth, and water was poured until the hole was filled. This creates the ideal conditions for both the material surrounding the electrode and for the mortar to adhere and attach to the pores of the electrode.

We subsequently employed a potentiostat, controlled by an Arduino hard development card, to perform more concrete measurements. The potentiostat carries out the LPR test using electrical relays, digital-to-analog converters, and an operational amplifier, releasing a sweep voltage of between $-20 \mathrm{mV}$ and $+20 \mathrm{mV}$ regarding the half-cell potential, with an increase of $10 \mathrm{mV}$ in one-second intervals. As a counter electrode, we used a graphite electrode embedded in the concrete. The polarization signal was applied, from which the current was obtained through an electrode.

The system had previously been outfitted with a GSM/GPRS M95 (Global System for Mobile communications/ General Packet Radio Service) communication module. Using a cellular network and an SIM card, we can then begin to operate the equipment via an incoming signal by way of text message. The open circuit potential data and the corrosion current data obtained from the LPR tests were forwarded to a web server for database storage and subsequent visualization on equipment with minimal access to the internet.

We manufactured three identical concrete test specimens with Type I Portland cement, each with a diameter of $15 \mathrm{~cm}$, a height of $30 \mathrm{~cm}$, and with steel reinforcements a half-inch in diameter. Each specimen was armed with the corrosion monitoring system to perform the tests and a Gamry PCI4 reference system to obtain contrast measurements to determine the mean error of the acquired data.

Once the half-cell potential was obtained, we used the linear polarization resistance (LPR) method to get the measurement parameters, such as the corrosion potential (Vcorr), polarization resistance (Rp), and corrosion current (Icorr), in accordance with ASTM standard G59. This test was performed by measuring the corrosion potential and applying a variable potential to an auxiliary electrode embedded in the concrete. We used a graphite auxiliary electrode, located two centimeters both from the rebar and from the reference electrode.

The voltage was applied at constant one-second intervals with $10 \mathrm{mV}$ increases, where the time interval is sufficient for the system to stabilize. After carrying out the test, the three electrodes automatically disconnect so as not to affect the stability of the system. The above procedure was repeated on each manufactured specimen, each having the polarization potential applied and obtaining the corrosion density as a response.

\section{Results and discussion.}

Figure 1 displays the responses in current at the five voltage steps. It corresponds to the $-20 \mathrm{mV}$ to $+20 \mathrm{mV}$ sweep applied from the obtained open circuit potential, of $-879.66 \mathrm{mV}$, via the LPR test, applied with the developed system.

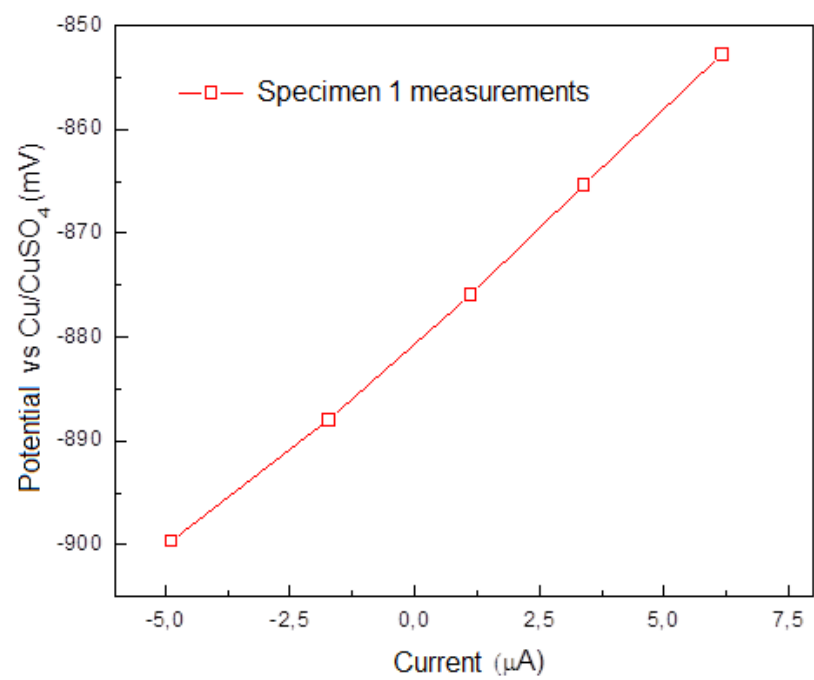

Figure 1 LPR Test Graphic, Specimen 1

Using the potential and current values, we calculated the linear polarization resistance ( $\mathrm{Rp}$ ) according to the equation $\mathrm{Rp}=\Delta \mathrm{V} / \Delta \mathrm{I}$, where $\mathrm{Dd}$ is the variation in voltage and $\mathrm{Dm}$ is the variable of variation in current. According to the performed calculation, the $\mathrm{Rp}$ value was determined to be 4242.31

Using the polarization resistance, the corrosion current Icorr was determined based on the equation Icorr $=\mathrm{B} / \mathrm{Rp}$, where the value $B$, in millivolts, is determined based on the area in which the rebar is located (passive area for locations external to corrosive processes, active areas for corrosive environments). This can be seen in Table 2

Table 2 Constant B

\begin{tabular}{|c|c|}
\hline Area & $\boldsymbol{B}(\boldsymbol{m} \boldsymbol{V})$ \\
\hline Passive & 26 \\
\hline Active & 50 \\
\hline
\end{tabular}

Using a $\mathrm{B}$ value of $50 \mathrm{mV}$, since the area was active, we obtained an Icorr value of $11.78 \mathrm{~mA}$. Lastly, in order to find the corrosion rate in millimeters per year (mmpy), we used the equation $\left(I_{\text {corr }} \cdot K \cdot W_{e}\right) /(d \cdot A)$ where $\mathrm{K}$ is the constant that defines the units of the corrosion rate, corresponding to a 


\section{TECCIENCLA}

value of 3272, whose units are millimeter per ampere centimeter year.

Meanwhile, we is the weight in equivalent grams of iron and $\mathrm{d}$ is its density in grams/cm3. Using the above equation on Specimen 1, we obtained a corrosion rate of $1.1018 \times 10-3$ mmpy.

According to Table 1, the corrosion potential of $-879.66 \mathrm{mV}$ corresponds to a probability of corrosion of $90 \%$ or greater, where the complementary LPR technique helps by corroborating the high level of corrosion with a considerable rate of deterioration. The results of the test are displayed in Table 3.

Table 3 Results of the test on Specimen 1

\begin{tabular}{|c|c|c|}
\hline Half-cell potential & \multicolumn{2}{|c|}{$-879.66 \mathbf{m V}$} \\
\hline $\begin{array}{c}\text { Response to a voltage step starting from } \\
\text { the half-cell potential }\end{array}$ & $\begin{array}{c}\text { Current } \\
\left(\mathbf{m A} / \mathbf{c m}^{2}\right)\end{array}$ & $\begin{array}{c}\text { Potential } \\
\text { (mV) }\end{array}$ \\
\hline Response to -20 mV step & -4.89 & -899.63 \\
\hline Response to -10 mV step & -1.73 & -887.98 \\
\hline Response to 0 mV step & 1.12 & -875.94 \\
\hline Response to 10 mV step & 3.39 & -865.36 \\
\hline Response to 20 mV step & 6.17 & -852.71 \\
\hline
\end{tabular}

The test on Specimen 2 was likewise performed following the procedure mentioned above (Table 4). We obtained a corrosion potential of $-880.70 \mathrm{mV}$, corresponding to a probability of corrosion of $90 \%$ and a rate of corrosion of 1.1026x10-3 mmpy, calculated with the LPR test (Figure 2).

Table 4 Results of the test on Specimen 2Half

\begin{tabular}{|c|c|c|}
\hline -cell potential & \multicolumn{2}{|c|}{$-880.79 ~ \mathbf{~ V}$} \\
\hline $\begin{array}{c}\text { Response to a voltage step } \\
\text { starting from the half-cell } \\
\text { potential }\end{array}$ & $\begin{array}{c}\text { Current } \\
\left(\square \mathbf{A} / \mathbf{c m}^{2}\right)\end{array}$ & $\begin{array}{c}\text { Potential } \\
\text { (mv) }\end{array}$ \\
\hline Response to -20 $\mathrm{mV}$ step & -4.69 & -901.35 \\
\hline Response to -10 mV step & -1.67 & -889.86 \\
\hline Response to 0 $\mathrm{mV}$ step & 1.23 & -877.76 \\
\hline Response to $10 \mathrm{mV}$ step & 3.92 & -866.34 \\
\hline Response to $20 \mathrm{mV}$ step & 6.15 & -854.69 \\
\hline
\end{tabular}

Finally, the tests were performed on the final specimen. These indicated a $90 \%$ probability of corrosion, based on the measured corrosion potential of $-883.09 \mathrm{mV}$. Likewise, the calculation for the rate of corrosion revealed a rate of $1.057 \times 10^{-3}$ mmpy. The test results can be seen in Figure 3 and the variations in

Once all the tests were carried out with the equipment we developed, they were repeated with commercial equipment, whose measurements were used as a point of reference to calculate the error in the previously obtained data (Figure 4, Table 6)

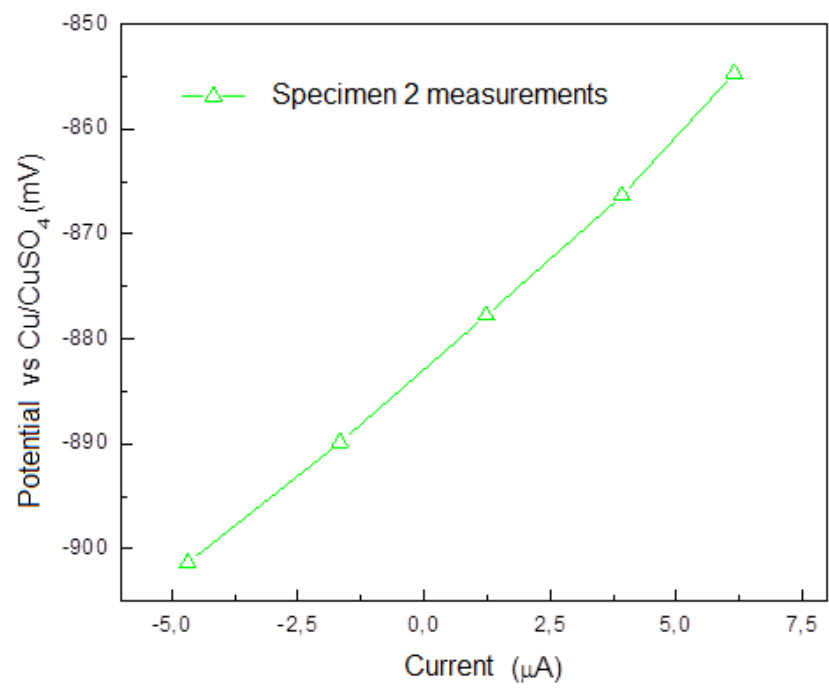

Figure 2 LPR Test Graphic, Specimen 2

Table 5 Results of the test on Specimen 3

\begin{tabular}{|c|c|c|}
\hline Half-cell potential & \multicolumn{2}{|c|}{$\mathbf{- 8 8 3 . 0 9}$ mV } \\
\hline $\begin{array}{c}\text { Response to a voltage step starting from } \\
\text { the half-cell potential }\end{array}$ & $\begin{array}{c}\text { Current } \\
\left(\mathbf{m A} / \mathbf{c m}^{2}\right)\end{array}$ & $\begin{array}{c}\text { Potential } \\
\text { (mv) }\end{array}$ \\
\hline Response to -20 mV step & -4.44 & -903.02 \\
\hline Response to -10 mV step & -1.43 & -889.78 \\
\hline Response to 0 mV step & 0.94 & -879.75 \\
\hline Response to $10 \mathrm{mV}$ step & 3.1 & -870.27 \\
\hline Response to $20 \mathrm{mV}$ step & 5.42 & -858.75 \\
\hline
\end{tabular}

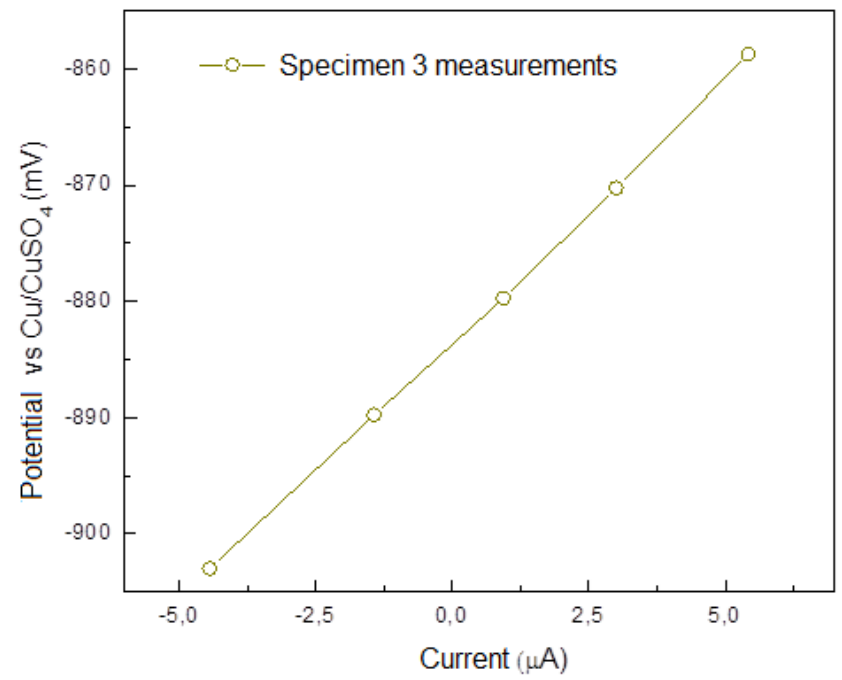

Figure 3 LPR Test Graphic, Specimen 3 


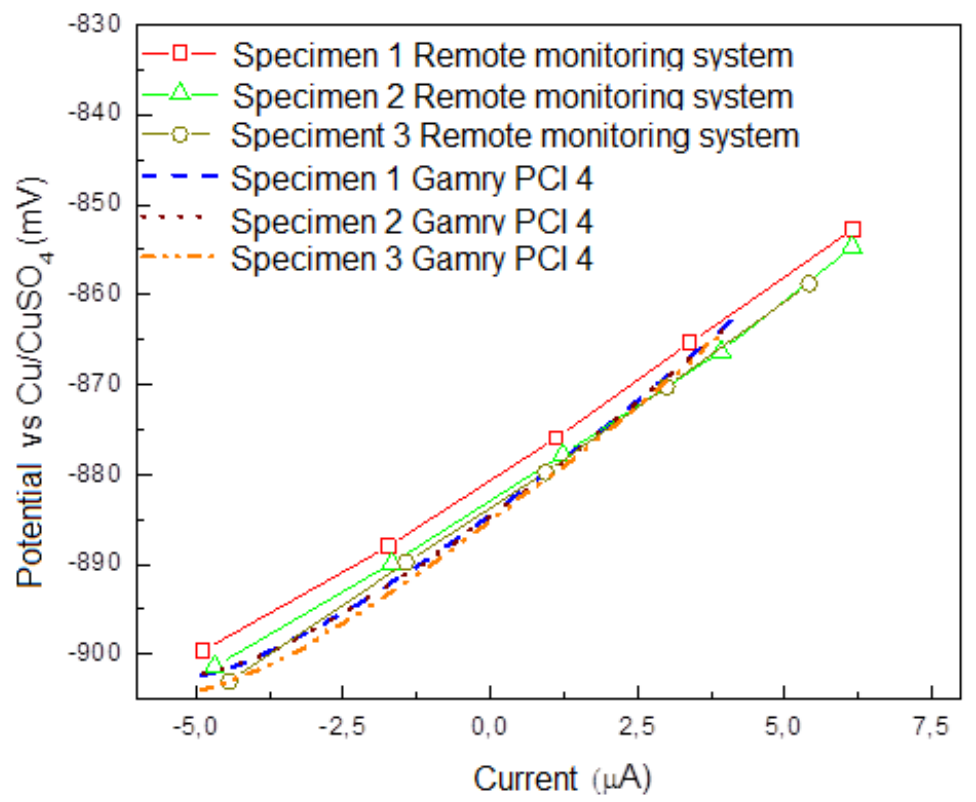

Figure 4 Comparison of the remote test system with the reference system

Table 6 Test results from the designed system and error obtained vs. the commercial system

\begin{tabular}{|c|c|c|c|c|c|c|}
\hline Specimen & $\begin{array}{c}\text { Corrosion potential vs } \\
\text { Cu/CuSO4 using the } \\
\text { monitoring system (mV) }\end{array}$ & $\begin{array}{c}\text { Measurement of } \\
\text { half-cell potential } \\
(\mathbf{m V}) \text { with GAMRY } \\
\text { PCI 4 }\end{array}$ & $\begin{array}{c}\text { Error of value } \\
\text { of half-cell } \\
\text { potential (\%) }\end{array}$ & $\begin{array}{c}\text { Resistance to } \\
\text { LPR (Ohm cm) }\end{array}$ & $\begin{array}{c}\text { Resistance to } \\
\text { LPR GAMRY } \\
\text { PCI 4 (Ohm cm) }\end{array}$ & $\begin{array}{c}\text { Error of } \\
\text { value of Rp } \\
(\mathbf{\%})\end{array}$ \\
\hline Specimen 1 & -879.66 & -882 & $0.27 \%$ & 4242.31 & 4330 \\
\hline Specimen 2 & -880.79 & -883 & $0.25 \%$ & 4304.42 & $2.2 \%$ \\
\hline Specimen 3 & -883.09 & -884 & $0.10 \%$ & 4489.85 & 4310 & $4.29 \%$ \\
\hline
\end{tabular}

Based on the errors calculated for the measurements of each of the specimens, we obtained an average error of $1.17 \%$ compared to the commercial equipment. Likewise, we calculated an average error of $0.26 \%$ over the half-cell potentials used to estimate the probability of corrosion.

\section{Conclusions}

According to the tests performed on the developed system, an average potential of $-881.18 \mathrm{mV}$ was obtained, corresponding to a probability of corrosion of $90 \%$ or greater for the three manufactured specimens. Moreover, the value of the probability of corrosion was supplemented with the calculation of the rate of corrosion using the obtained LPR values, finding an average value of $1.087 \times 10-3$ for the three specimens.

We determined, using the analyzed data, which the developed system has a minimum error of $0.03 \%$ and a maximum error of $2.2 \%$ compared to the commercial equipment. There was an average error of $1.17 \%$ for polarization resistance and $0.26 \%$ for corrosion potential.
With this, it is possible to determine the reliability of the data obtained with our system.

Given the connectivity of the system, via the GSM network, it can be installed in a diverse variety of locations and can maintain the precision of the performed tests, thus presenting significant advantages compared to the option of frequently dispatching personnel and equipment to the field to carry out tests with commercial devices.

This study demonstrated a system capable of performing half-cell potential measurements in a range of $\pm 1200 \mathrm{mV}$, with a precision of $\pm 1 \mathrm{mV}$ and sampling rate of one second. Such a configuration provides the capacity of acquiring 900 measurements per test, guaranteeing the procurement of a true half-cell potential.

\section{Acknowledgements}

The above was a product of the ING 1760 project, financed by the Vice Rectory of research at UMNG, 2015 term, and research working groups at the 2013 Colciencias conference. 


\section{TECCIENCIA}

\section{References}

[1] B. Pradhan y B. Bhattacharjee, «Performance evaluation of rebar in chloride contaminated concrete by corrosion rate,» Cunstruction and Building materials, vol. 23, nº 6, pp. 2346-2356, 2009.

[2] A. A. Allmusallam, «Effect of degree of corrosion on the properties of reinforcing steel bars,» Construcion and building materials, vol. $15, \mathrm{n}^{\circ} 8$, pp. 361-368, 2001.

[3] F. Tang, G. Chen, R. K. Brow, J. S. Volz y M. L. Koengstein, «Corrosion resistance and mechanism of steel rebar coated with three types of enamel,» Corrosion Science, vol. 59, $\mathrm{n}^{\circ}$ 1, pp. 157-168, 2012.

[4] G. Roa- Rodriguez, W. Aperador y A. Delgado, «Calculation of Chloride Penetration Profile in ConcreteStructures,» International Journal of electrochemical Science, vol. 8, $\mathrm{n}^{\circ} 1$, pp. 5022-5035, 2013.

[5] W. Aperador, A. Delgado y E. Vera, «Monitoreo mediante EIS del acero embebido en un concreto de escoria activada alcalinamente expuesto a carbonatación,» Revista ingeniería de construcción, vol. 26, $\mathrm{n}^{\circ} 1$, pp. 81-94, 2011

[6] W. Aperador, R. Mejía de Gutiérrez y D. M. Bastidas, «Steel corrosion behaviour in carbonated alkali-activated slag concrete,» Corrosion Science, vol. 51, nº 9, pp. 2027-2033, 2009.

[7] J. P. Balayssac, C. H. Dériché y J. Grandet, «Effects of curing upon carbonation of concrete,» Construciotion and Building Materials, vol. 9, no 2, pp. 91-95, 1995.

[8] W. Aperador Chaparro, E. Vera López y R. Mejía de Gutiérrez, «Corrosion behavior fo steel bar embedded in alkali- activated slag concrete subjected to carbonation and chloride attack,» Dyna, Revista facultad Nacional de MInas, vol. 79, n 171, pp. 80-87, 2012.

[9] G. Roa Rodríguez, W. Aperador Chaparro y R. Vera Aravena, «Sofware para el cálculo de la velocidad de deterioro de los hormigones sometidos a carbonatación,» Revista latinoamericada de metalurgia y materiales, vol. 34, $\mathrm{n}^{\circ}$ 1, pp. 45-54, 2014. 